\title{
Sound production by dusky grouper Epinephelus marginatus at spawning aggregation sites
}

\author{
F. Bertucci*†, P. Lejeune $\$$, J. Payrot§ and E. Parmentier* \\ *Laboratory of Functional and Evolutionary Morphology, AFFISH-RC, University of Liège, \\ Campus du Sart Tilman, Institut de Chimie Bat.B6c, 4000 Liège 1, Belgium, $\ddagger$ STARESO \\ research station, Pointe de la Revellata, BP33, 20260 Calvi, France and \$Natural Marine \\ Reserve of Cerbère-Banyuls, 5 rue Roger David, 66650 Banyuls sur Mer, France
}

(Received 12 February 2015, Accepted 21 May 2015)

\begin{abstract}
Sound production by the dusky grouper Epinephelus marginatus was monitored both in captivity and at two Mediterranean spawning sites during the summers of 2012 and 2013. The results of long-term passive acoustic recordings provide for the first time a description of the sounds produced by $E$. marginatus. Two types of sounds were mainly recorded and consisted of low-frequency booms that can be produced singly or in series with dominant frequencies below $100 \mathrm{~Hz}$. Recordings in captivity validated these sounds as belonging to E. marginatus and suggested that they may be associated with reproductive displays usually performed during early stages of courtship behaviour. This study also allowed the identification of a third, low-frequency growl-like type of sound typically found in other grouper species. These growls were, however, not recorded in tanks and it is cautiously proposed that they are produced by E. marginatus. Acoustic signals attributed to E. marginatus were produced throughout the spawning season, with a diel pattern showing an increase before dusk, i.e. from 1900 to 2200 hours, before decreasing until the morning. The occurrence of sounds during the spawning season of this species suggests that they are probably involved in social activity occurring close to aggregation sites. Passive acoustics offer a helpful tool to monitor aggregation sites of this emblematic species in order to improve conservation efforts.
\end{abstract}

(C) 2015 The Fisheries Society of the British Isles

Key words: animal communication; conservation; Mediterranean Sea; passive acoustics; reproductive behaviour.

\section{INTRODUCTION}

Numerous species of marine fishes are known to produce sounds in association with aggressive postures and with courtship displays (Fish \& Mowbray, 1970; Ladich \& Myrberg, 2006). These behaviours occur particularly within the spawning season, during which an increased vocal activity has been associated with reproductive activities in many families such as the Sciaenidae (Connaughton \& Taylor, 1995; Locascio \& Mann, 2008), Pomacentridae (Mann \& Lobel, 1995; Parmentier et al., 2010), Batrachoididae (McKibben \& Bass, 1998), Percidae (Johnston \& Johnson, 2000), Gadidae (Hawkins \& Amorim, 2000), Gobiidae (Malavasi et al., 2009; Parmentier et al., 2013)

$\dagger$ Author to whom correspondence should be addressed. Tel.: +32 $4 \quad 366 \quad 50$ 33; email: f.bertucci@student.ulg.ac.be 
or Ophidiidae (L. Kever \& E. Parmentier, unpubl. data). Besides their role during courtship interactions (e.g. announcing male readiness to spawn, attracting gravid females and synchronizing gamete release), sounds may have other functions such as territorial defence or aggregating group members (Myrberg \& Lugli, 2006). Monitoring sound production may therefore allow different aspects of the biology of fishes to be investigated.

In recent years, passive acoustics has been used as a non-invasive method to perform continuous monitoring of fishes over long periods of time by using sound production as a reliable natural acoustic signal to detect fish aggregation sites or to identify and follow seasonal activities of soniferous species in the field (Mann \& Lobel, 1995; Luczkovich et al., 1999, 2008). This method has thus become a useful tool in conservation studies.

Many representatives of the family Serranidae have already been documented to produce sounds (Table I). Acoustic signals of the goliath grouper Epinephelus itajara (Lichtenstein 1822) (Mann et al., 2009), the red hind Epinephelus guttatus (L. 1758) (Mann et al., 2010), the red grouper Epinephelus morio (Valenciennes 1828) (Nelson et al., 2011), the yellowfin grouper Mycteroperca venenosa (L. 1758) (Schärer et al., 2012a), the Nassau grouper Epinephelus striatus (Bloch 1792) (Schärer et al., 2012b) and the black grouper Mycteroperca bonaci (Poey 1860) (Schärer et al., 2014) have recently been characterized at spawning locations by means of passive acoustic recording. In these grouper species, results show that sounds are made during the spawning period and are associated with courtship behaviour, supporting the idea that the sounds are related to spawning activity.

The dusky grouper Epinephelus marginatus (Lowe 1834) is a serranid distributed from the British Isles (although rare) to South Africa, from the Bermuda Islands to Argentina and is widespread in the Mediterranean Sea (Heemstra \& Randall, 1993; Irigoyen et al., 2005). It is considered as an emblematic species, closely associated with the Mediterranean rocky and reef habitat (Pastor et al., 2009). The species is considered overexploited in its entire distribution range (Reñones et al., 1999; Coll et al., 2004) and is classified as endangered in the IUCN red list of threatened species (Cornish \& Harmelin-Vivien, 2004). Epinephelus marginatus is a territorial species that inhabits shelter-rich, hard substrata to depths of $250 \mathrm{~m}$ with maximum densities $<50 \mathrm{~m}$ in depth (Harmelin \& Harmelin-Vivien, 1999; La Mesa et al., 2002). The common colour consists of a dark-brown body with a white mottled pattern. Epinephelus marginatus, however, shows also a variety of colour patterns that can change during the reproductive season according to the size class, sex or condition of individuals (Louisy, 1996; Zabala et al., 1997a,b). As an example, male individuals present more white blotches on their body at the beginning and at the end of the spawning season. This pattern turns into a silver streaked territorial template in dominant males. In September, probably because of physical and physiological fatigue, the same individuals can display an overall light grey pattern (Zabala et al., 1997b). Epinephelus marginatus is a monandric protogynous hermaphrodite species in which mature female size ranges between c. 40 and $100 \mathrm{~cm}$ total length $\left(L_{\mathrm{T}}\right)$ while males are generally larger and vary from $c$. 60 to $120 \mathrm{~cm} L_{\mathrm{T}}$ (Reñones et al., 2010). The largest individuals are sedentary and territorial with a high degree of site fidelity during winter and early spring when their activity and density are low (Zabala et al., 1997b; Lembo et al., 2002; Pastor et al., 2009). Large males, however, can stay out of their shelters and swim in open water (Zabala et al., 1997b). 
SOUNDS OF EPINEPHELUS MARGINATUS

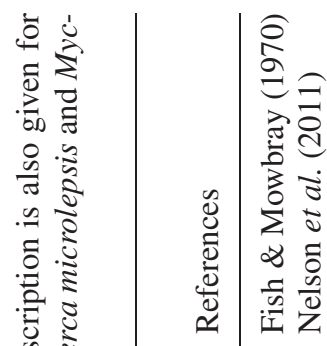

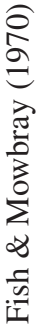

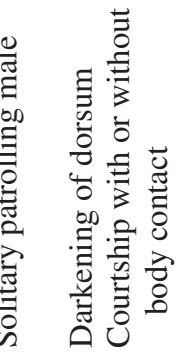

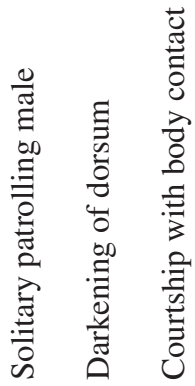

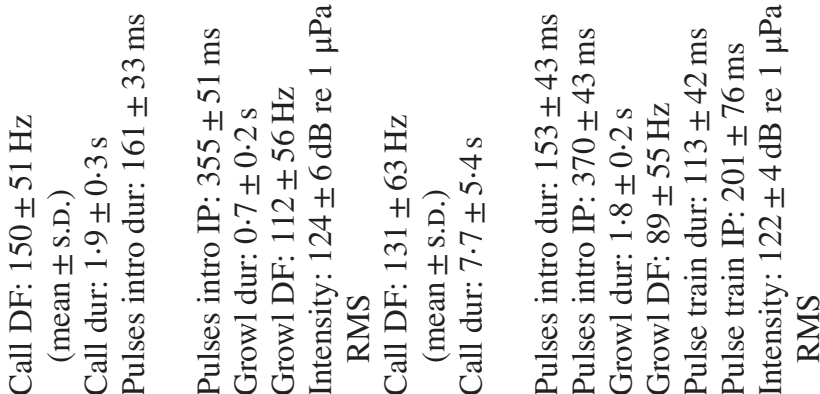

एँ

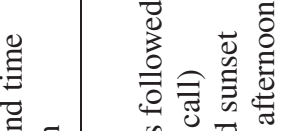

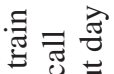

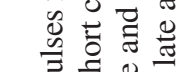

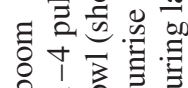

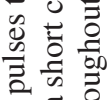

ำ

1.

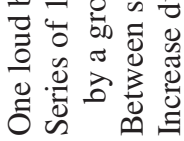

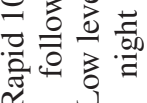

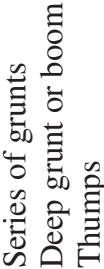

ति $\frac{2}{2}$

츨

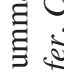

i.

됙

这章 


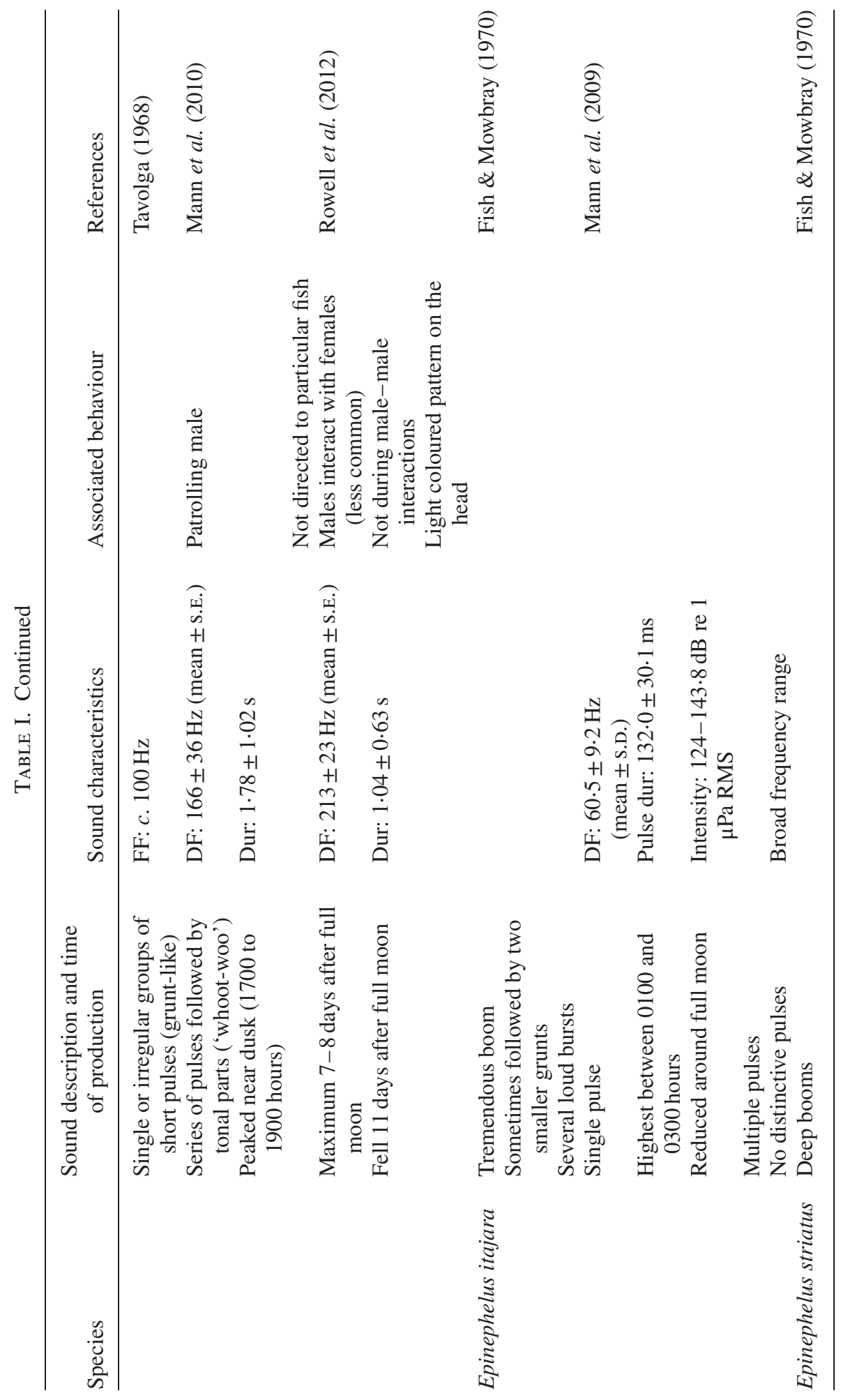


SOUNDS OF EPINEPHELUS MARGINATUS

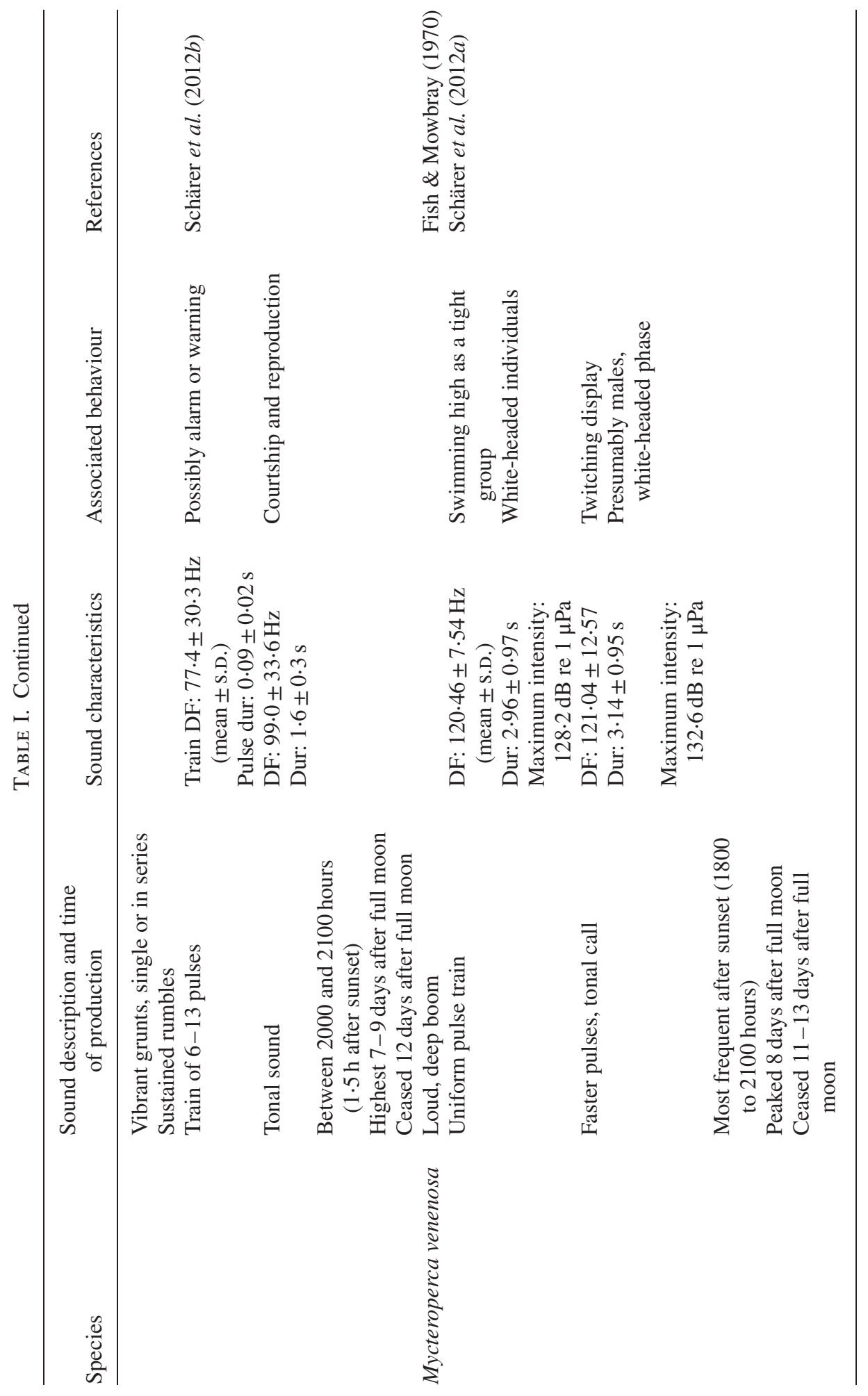


F. BERTUCCI ET AL.

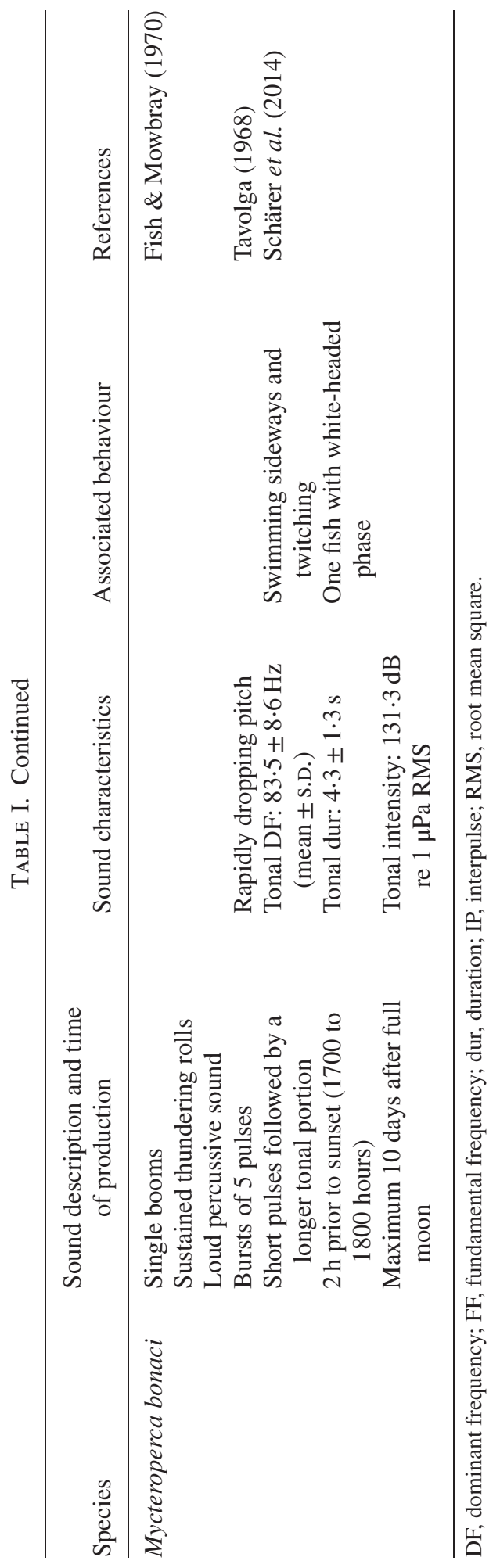


In the Mediterranean Sea, individuals become more active from May to July and aggregate at specific locations in order to spawn (Zabala et al., 1997b). The sex ratio during the spawning season is $c$. 1 male: 2 females (Bruslé \& Bruslé, 1976). As non-territorial males and immature females do not take part in spawning, Zabala et al. (1997b) proposed a 'territorial male-adult female' ratio of 1:7. Prior to spawning, male territorial activity is the most conspicuous behaviour observed. It consists of males patrolling all day long, swimming rapidly and chasing conspecifics, especially male neighbours. During encounters, males show frontal and lateral displays with tail fluttering, sometimes tilting their bodies (Zabala et al., 1997b). In the evening, males patrol a smaller zone to which females may enter in order to mate. In front of a receptive female, the aggressive behaviour switches to courtship and leads to spawning. Zabala et al. (1997a) described four main phases of spawning behaviour in E. marginatus, i.e. the approach of the male, a series of vertical ascents with no spawning (false rises), a final spawning rush with the release of the gametes and finally, the separation of the mates. All this happens at dusk and during the night. All the above-mentioned behaviours are associated with specific colour patterns (Zabala et al., 1997a, b). Most of the reproductive activity occurs between late June and late September with spawning peaks occurring in July and August (Zabala et al., 1997a, b; Marino et al., 2001; Hereu et al., 2006; Reñones et al., 2010). During summer, divers have reported loud booming sounds near E. marginatus aggregation sites (pers. comm.).

The general aim of this study was to describe for the first time the sounds of $E$. marginatus and to validate the use of passive acoustics in the monitoring of this species. The two mains objectives were (1) to characterize the sounds produced by E. marginatus during its spawning season in situ, as well as the behaviour associated with sound production observed in captivity and (2) to describe the temporal pattern of sound production by means of long-term passive acoustic recordings made at two locations in the Mediterranean Sea.

\section{MATERIALS AND METHODS}

\section{RECORDINGS AT SEA}

In 2012, long-term passive acoustic recordings were made off the north-western coast of Corsica (France) at La Revellata headland $\left(42^{\circ} 35^{\prime} \mathrm{N} ; 08^{\circ} 45^{\prime} \mathrm{E}\right.$; depth $\left.=36 \mathrm{~m}\right)$ where $E$. marginatus have previously been observed to aggregate (P. Lejeune, pers. comm.). The sea surface temperature was monitored by means of a conductivity-temperature-depth probe routinely sampled at STARESO harbour. In 2013, passive acoustic recordings were again performed at La Revellata and also in the Marine Reserve of Cerbère-Banyuls ( $42^{\circ} 28^{\prime} \mathrm{N} ; 03^{\circ} 10^{\prime} \mathrm{E}$; depth $\left.=18 \mathrm{~m}\right)$. Pas-

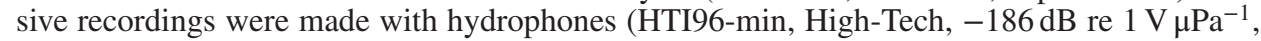
$20 \mathrm{~dB}$ gain; www.hightechincusa.com) connected to underwater digital spectrogram (DSG) Long-term acoustic recorders (Loggerhead Instruments; www.loggerhead.com). In 2012, the device was scheduled to record 10 min every hour from 27 June to 2 October, yielding a total of 2256 files. In 2013, two devices were scheduled to record 5 min every hour from 1 July to 30 September 2013 at La Revellata and 6 min every hour from 9 July to 30 September at Cerbère-Banyuls reserve to yield a total of 2497 and 1965 files, respectively. Acoustic signals were digitized at $20 \mathrm{kHz}$ and stored on 32-GB SD cards. DSG recorders were weighted by a block of concrete, positioned on the seabed by divers and stayed in place during the entire course of the experiments. Both sites were specifically chosen because they are well known to contain territorial E. marginatus, and the hydrophones were placed close to the spawning sites. No other grouper species were reported at these locations (P. Lejeune \& J. Payrot, pers. comm.). 


\section{RECORDINGS IN CAPTIVITY}

Recordings were made in two different public aquaria. In the aquarium of La Cité de la Mer in Cherbourg (France) from 26 March to 30 March 2013, two individuals (a female of $c$. 60-65 cm and a male of $c .75-80 \mathrm{~cm} L_{\mathrm{T}}$ ) were housed together (water temperature: $c .17^{\circ} \mathrm{C}$ ). In the aquarium of Banyuls sur Mer (France) from 5 July to 08 July 2013, two individuals (undetermined sex, c. 70-75 and $85-90 \mathrm{~cm} L_{\mathrm{T}}$ ) were housed in separate tanks (water temperature: $c .20^{\circ} \mathrm{C}$ ). A total of 21 and 22 recordings, respectively, of 10 min each were made during opening hours of the aquaria, when public attendance was the lowest. The number of individuals recorded was quite low because of the difficulty of keeping these large animals in captivity. The purpose was to investigate the species specificity of acoustic signals in order to validate sounds heard in the wild as belonging to E. marginatus. All tanks contained additional species such as nursehound Scyliorhinus stellaris (L. 1758), small-spotted catshark Scyliorhinus canicula (L. 1758), red scorpionfish Scorpaena scrofa L. 1758, European seabass Dicentrarchus labrax (L. 1758) or gilthead seabream Sparus aurata L. 1758. A hydrophone (HTI-96-Min; sensitivity: $-164.4 \mathrm{~dB}$ re $1 \mathrm{~V} \mu \mathrm{Pa}^{-1}$; flat frequency response ranges between $0 \cdot 2$ and $30 \mathrm{kHz}$ ) connected to a TASCAM DR-07 portable digital recorder (www.tascam.com/product/dr-07) was used. Acoustic activity was monitored with the recording device set to recording standby mode. When a sound was produced, the recording was started and included the two preceding seconds. The recording was set back to standby if sounds were no longer produced. Sounds were digitized at $44 \cdot 1 \mathrm{kHz}$ (16-bit resolution). Recording sessions were video-recorded by means of a digital video camera (Sony Handycam DCR-SR Series, Sony Corporation; www.sony.com) positioned in front of the tanks in order to link potential sound production to specific behaviour and posture. Recording sessions lasted $20 \mathrm{~min}$ and were distributed over the day especially during low visitation, i.e. from 0900 to 1000 , from 1200 to 1400 and from 1700 to 1900 hours.

\section{GENERAL ACOUSTICAL ANALYSIS}

Passive acoustic recordings were down-sampled to a sampling rate of $1000 \mathrm{~Hz}$, and a $10-500 \mathrm{~Hz}$ band-pass filter was applied. Sounds were detected by visual inspection of spectrograms [Fast Fourier Transform (FFT) 512 points Hamming window] with a $30 \mathrm{~s} \mathrm{time}$ window using the Avisoft SASLab Pro 5.2.07 software (www.avisoft.com/soundanalysis). At sea and in tanks, only sounds with a good signal-to-noise ratio were used for the analysis. The following variables were measured from oscillograms: number of pulses per sound, pulse duration (ms), pulse period (peak-to-peak interval, ms) and total sound duration (from the start of the first pulse to the end of the last pulse, ms). The frequency composition of the sounds was measured from logarithmic power spectra (FFT, 512 points Hamming window). Data of acoustic features were normally distributed and met the assumptions of parametric statistics. A $t$-test and ANOVAs were therefore used to compare acoustic features of sounds from the different sites and conditions (field $v$. captivity).

Seasonal sound production series were obtained by plotting the daily sum of sounds attributed to E. marginatus recorded per 5 min periods. Daily sound production series were created by plotting the mean number of sounds per min of recording with a $1 \mathrm{~h}$ resolution. Data were not normally distributed and Kruskal-Wallis tests were used in order to compare the number of sounds recorded every hour. The proportions of the different sound types recorded in Cerbère-Banyuls reserve were compared with Friedman ANOVAs by separating the day into four $6 \mathrm{~h}$ phases.

\section{RESULTS}

\section{ACOUSTIC REPERTOIRE AND CHARACTERISTICS}

Two different kinds of sounds were attributed to E. marginatus. They consisted of single booms and serial booms, which were recorded in tanks and in the field. Growling sounds were only recorded in the field and may potentially belong to E. marginatus. 


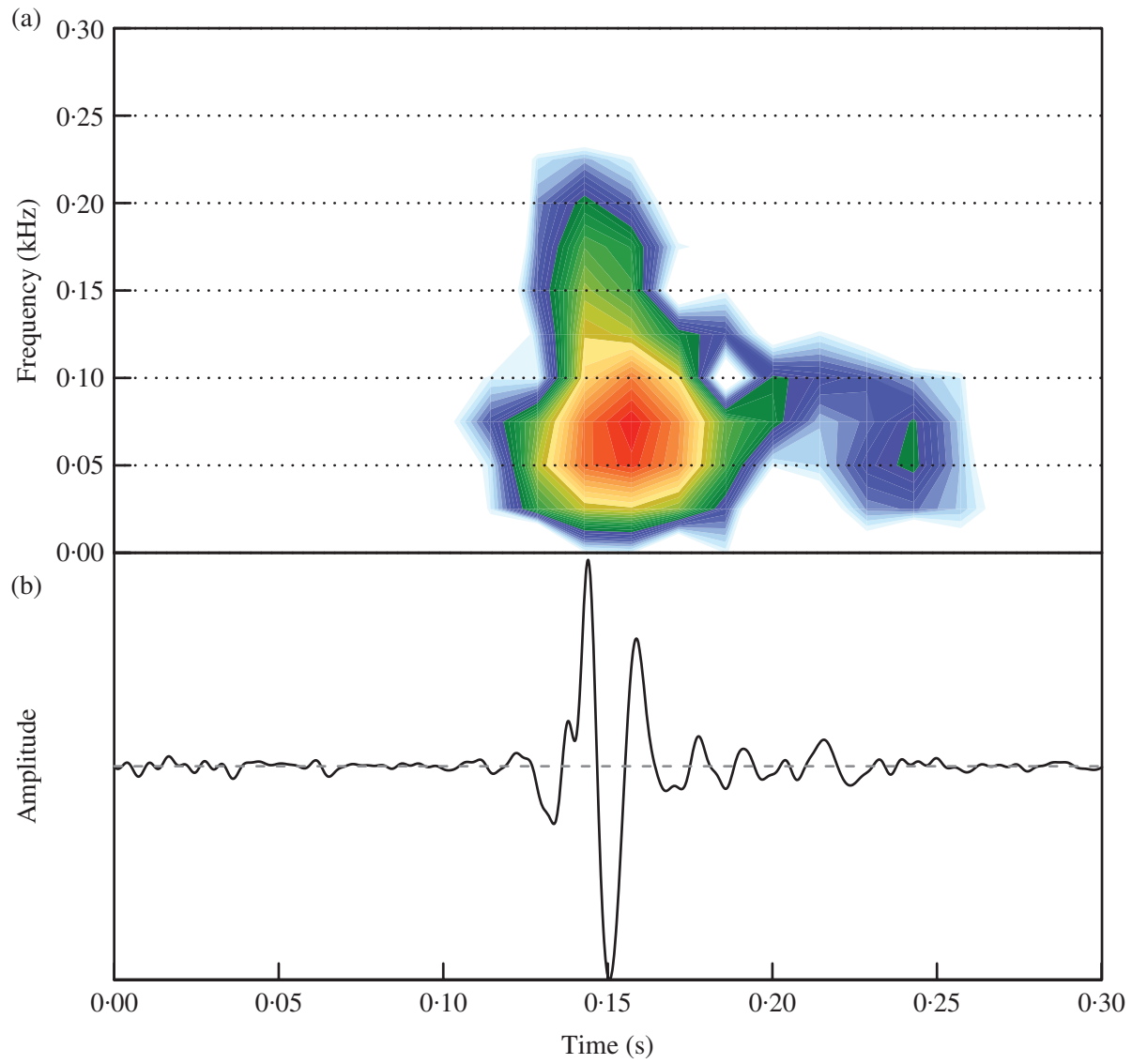

FIG. 1. (a) Spectrogram and (b) oscillogram of a single boom produced by Epinephelus marginatus and recorded at sea in Cerbère-Banyuls reserve. Colours indicate relative sound intensity (blue $=$ low and red $=$ high).

\section{Single booms}

Single booms were the most common sounds of E. marginatus recorded at sea (Fig. 1). Due to a high background noise and probably because the hydrophone was too far from the spawning site, only recordings from 2012 were used for quantitative analysis. Most of the sounds detected consisted mainly of frequencies below $150 \mathrm{~Hz}$. At La Revellata, single booms recorded in 2013 had a duration of $76 \pm 19 \mathrm{~ms}$ (mean \pm S.D.) and a dominant frequency of $107 \pm 28 \mathrm{~Hz}(n=27)$. In the Cerbère-Banyuls reserve, single booms $(n=70)$ had a duration of $95 \pm 23 \mathrm{~ms}$ and a dominant frequency of $68 \pm 19 \mathrm{~Hz}$. Sounds recorded at Cerbère-Banyuls were significantly longer than sounds from La Revellata ( $t$ test, $t_{18,38}=3 \cdot 32, P<0 \cdot 001$ ).

Such loud single pulses with a low frequency were recorded during day time in captivity in the aquarium of Banyuls-sur-Mer. Dominant frequency was $45 \pm 15 \mathrm{~Hz}(n=14$ sounds recorded from two individuals). Pulse and sound durations were hardly measurable due to background noise and reverberation from the walls of the tank. These single booms were produced when a heterospecific approached or entered the shelter of a grouper. 


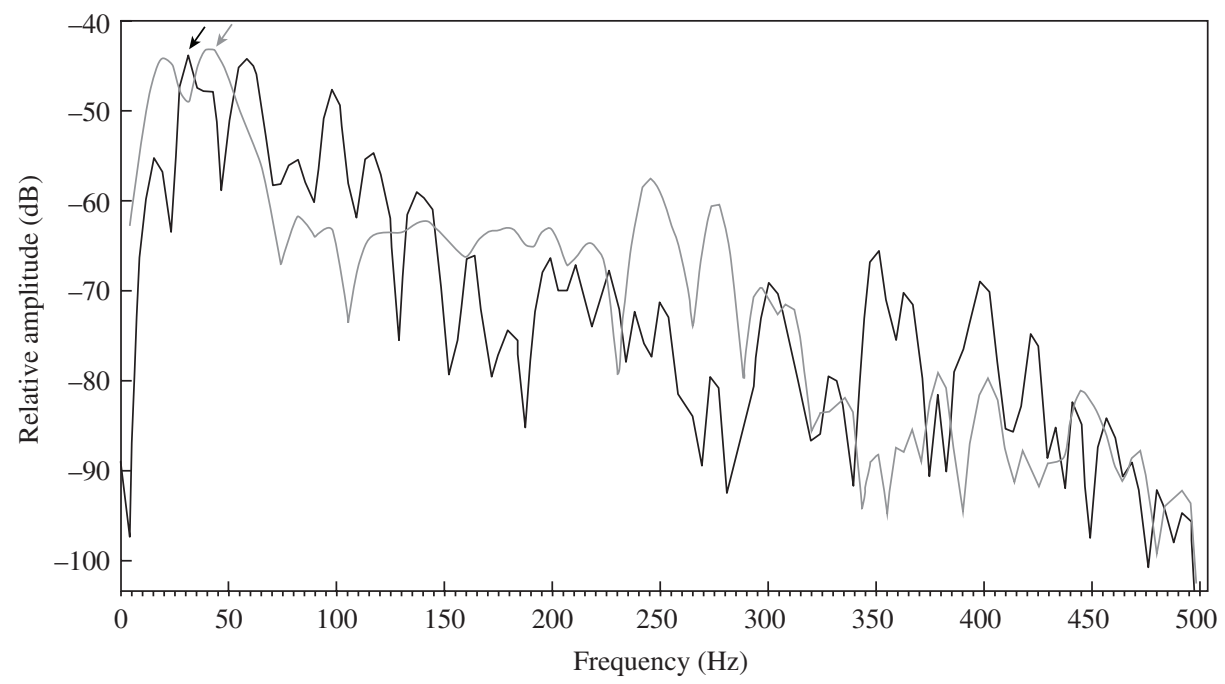

FIG. 2. Power spectra of a single boom by Epinephelus marginatus recorded at sea in Cerbère-Banyuls reserve $\left({ }\right.$ ) and at the aquarium of Banyuls sur Mer ( $\_$). $\rightarrow, \rightarrow$ dominant frequencies.

All the dominant frequencies were significantly different with the lower values being recorded in the aquarium of Banyuls-sur-Mer and the higher values recorded at La Revellata (ANOVA, $F_{2,108}=55 \cdot 6, P<0 \cdot 001$, least significant difference (LSD) post hoc tests, all $P$ values $<0 \cdot 001)$. Despite these statistical differences, most probably due to the low number of E. marginatus in tanks, the comparison of oscillograms and power spectra from sounds recorded at sea and from sounds recorded in captivity showed similar patterns (Fig. 2), validating that all these booms are produced by E. marginatus.

\section{Serial booms}

A second type of sound consisted of serial booms. Serial booms were rarely recorded at La Revellata to be analysed. Series recorded in Cerbère-Banyuls reserve in 2013 lasted $1572 \pm 671 \mathrm{~ms}$, were composed of $4 \pm 2$ pulses with a pulse duration of $78 \pm 16 \mathrm{~ms}$, a pulse period of $335 \pm 70 \mathrm{~ms}$ and their dominant frequency was $40 \pm 10 \mathrm{~Hz}(n=120)$.

From video recordings and observations performed at the aquarium of La Cité de la Mer in Cherbourg, this sound type was produced during interactions between a male and a female. The presumptive male swam towards the presumptive female until it was positioned close to it. The male subsequently leant almost horizontally on its flank and produced a series of caudal twitches with simultaneous production of sounds. While performing this behaviour, the male changed its colour pattern and briefly displayed bright silver stripes on its head and a large silver spot behind the opercular region [Fig. 3 and Video S1 (Supporting Information)]. No colour change was noticed in the female. Booms emitted in series were more discrete and quieter than single booms, reducing the degree of reverberation. These sounds ( $n=19$ sounds recorded from one individual in tank) lasted $712 \pm 360 \mathrm{~ms}$ and were composed of $3 \pm 1$ pulses with a pulse duration of $52 \pm 11 \mathrm{~ms}$ and a pulse period of $321 \pm 40 \mathrm{~ms}$. Their dominant frequency was $45 \pm 11 \mathrm{~Hz}$ (Fig. 4). The same sound type was recorded on 
(a)

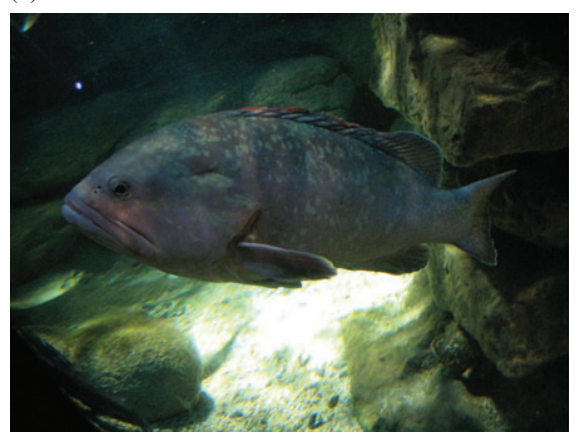

(b)

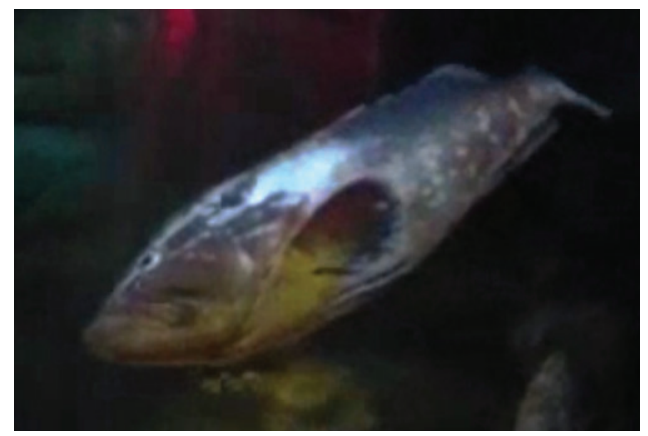

FIG. 3. Images of a captive presumptive male individual Epinephelus marginatus $\left(c .80 \mathrm{~cm}\right.$ total length, $\left.L_{\mathrm{T}}\right)$ in the (a) standard mottled colour pattern and (b) silver bright colour pattern displayed when interacting with a presumptive female (extracted from the video footage presented as Video S1, Supporting Information).

two occasions when an individual chased an S. scrofa at the Aquarium of Banyuls sur Mer, but no associated visual display or colour changes were observed.

Sounds recorded at sea had a significantly longer total duration $\left(t\right.$-test, $t_{7,18}=4 \cdot 18$, $P<0 \cdot 001)$, longer pulse duration $\left(t\right.$-test, $\left.t_{80,55}=10 \cdot 46, P<0.001\right)$ and lower dominant frequency $\left(t\right.$-test, $\left.t_{120,55}=2 \cdot 97, P<0 \cdot 01\right)$ than sound recorded in captivity. Numbers of pulses and pulse periods showed no significant differences. Moreover, the power spectra showed a similar profile for serial booms recorded at sea and in captivity (Fig. 5).

\section{Growls}

A third type of sound, defined as a growl, was often recorded at sea in CerbèreBanyuls reserve and more rarely at La Revellata (probably due to the distance of the hydrophone from the calling individuals). It consisted of short multi-harmonic calls lasting $256 \pm 116 \mathrm{~ms}$ with a fundamental frequency $\left(H_{0}\right)=86 \pm 13 \mathrm{~Hz}(n=34)$, which was always the dominant frequency. The first harmonic $\left(H_{1}\right)=167 \pm 31 \mathrm{~Hz}$ and the second harmonic $\left(\mathrm{H}_{2}\right)=265 \pm 41 \mathrm{~Hz}$. Higher harmonics were weak or absent. These frequencies showed a slight downward frequency modulation (Fig. 6). Growls were not stereotyped and could be produced in series of $1-3$.

\section{TEMPORAL PATTERN OF SOUND PRODUCTION DURING THE RECORDING PERIOD}

For all sound types, no significant changes were found in any of the acoustical features during the recording period. At La Revellata, vocal activity was detected throughout the recording period with an increased number of sounds recorded in July and in early September during 2012, and in August and September during 2013. Periods of increased sound production lasted 2-5 days. The pattern was different in 2013 in the Cerbère-Banyuls reserve where more sustained sonic activity was recorded throughout the recording period. Sound production did not appear to follow a lunar cycle at either site (Fig. 7).

Booming sounds (single and serial) were detected during night and day. Nevertheless, all recordings showed a marked pattern, with an increased number of sounds 


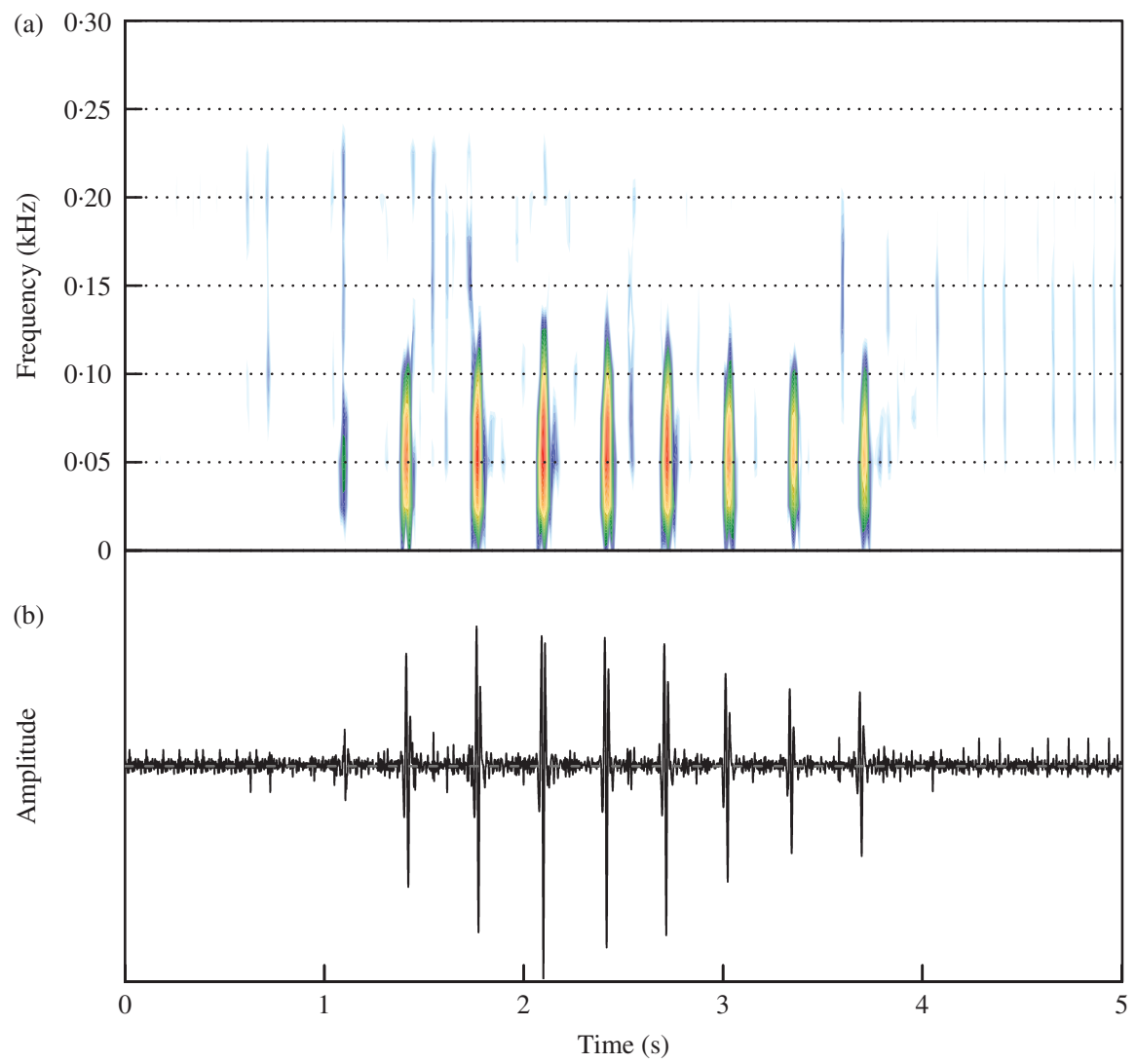

FIG. 4. (a) Spectrogram and (b) oscillogram of nine serial booms produced by Epinephelus marginatus. Colours indicate relative sound intensity (blue $=$ low and red $=$ high).

at dusk, peaking at 2200 hours before dropping off during the night until sunrise. During the day, booming sound production remained more constant, increasing slightly in the morning until 1400 to 1500 hours (Kruskal-Wallis tests, La Revellata, 2012: $H_{23,2047}=84 \cdot 86$; La Revellata, 2013: $H_{23,1184}=110 \cdot 64$; Cerbère-Banyuls: $H_{23,1729}=173 \cdot 25$, all $P<0 \cdot 001$ ) (Fig. 8). The high number of serial booms detected in Cerbère-Banyuls reserve in 2013 showed the same diel pattern, although the morning increase was stronger (Kruskal-Wallis test: $H_{23,1729}=97 \cdot 30$, all $P<0 \cdot 001$ ). Single booms and serial booms represented 60 and $35 \%$ of sounds recorded in the Cerbère-Banyuls reserve, respectively. The proportion of booms significantly increased up to $69 \%$ of sounds recorded during the 0000 to 0500 hour phase and $65 \%$ of sounds recorded during the 1800 to 2300 hour phase (Friedman ANOVA, $\left.F_{3,20}=14.33, P<0.001\right)$ while the percentage of serial booms significantly dropped to 22 and $30 \%$, respectively (Friedman ANOVA, $F_{3,20}=25 \cdot 71, P<0 \cdot 001$; Fig. 9).

Growls detected in Cerbère-Banyuls represented $5 \%$ of the total number of sounds and were also predominantly produced at night, increasing at dusk from 1900 hours and presented three peaks of production from 2200 to 0400 hours before decreasing until sunrise (Kruskal-Wallis tests, Cerbère-Banyuls: $H_{23,1729}=93 \cdot 49, P<0 \cdot 001$ ) (Fig. 10). 


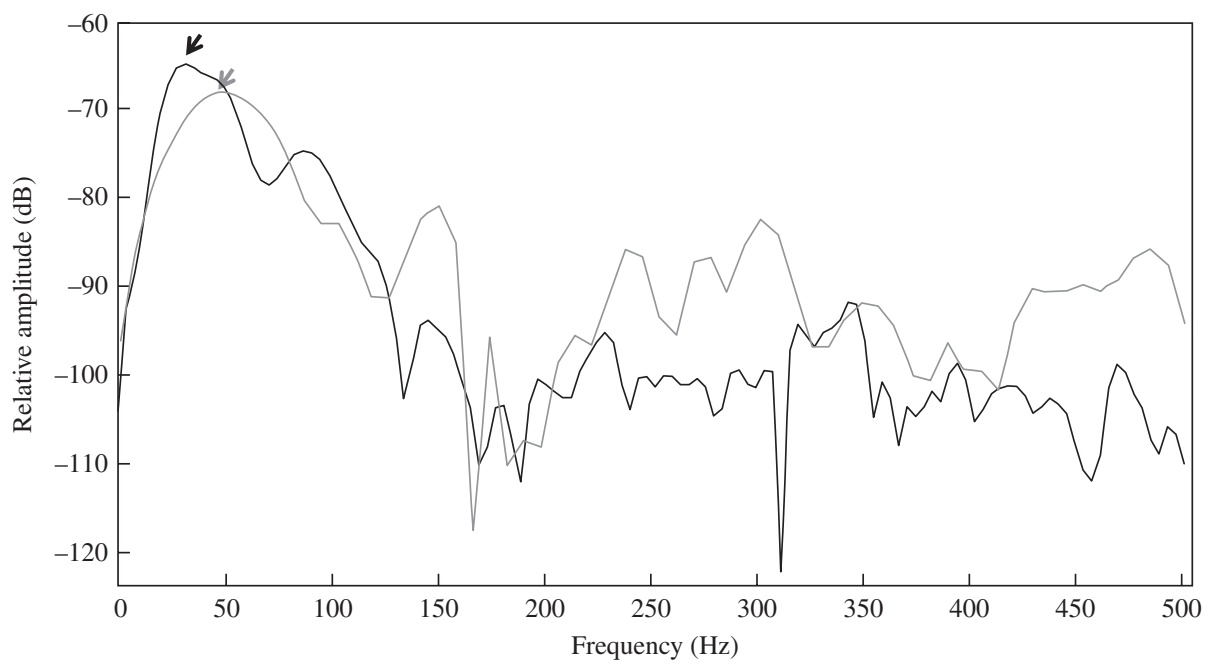

FIG. 5. Power spectra of serial booms by Epinephelus marginatus recorded at sea in Cerbère-Banyuls reserve $({ }$ ) and at the aquarium of La Cité de la Mer in Cherbourg (__ $) . \rightarrow, \rightarrow$ dominant frequencies.

Their proportion was significantly higher during the 0000 to 0500 hour phase (Friedman ANOVA, $F_{3,20}=20.93, P<0 \cdot 001$; Fig. 9).

\section{DISCUSSION}

The results of a passive acoustic survey conducted at known spawning aggregation sites of E. marginatus at two locations in the Mediterranean Sea are presented. Additional recordings and behavioural observations performed in captivity revealed the potentially important social role of acoustic signals in E. marginatus. Two main sound types were identified, i.e. loud single booms and serial booms. Another sound type consisted of short growling sounds. Overall, the sounds of Mediterranean E. marginatus appear to have a low frequency range $(<100 \mathrm{~Hz})$ and to be made of single or serial booms which can be rapidly repeated to produce growls.

Observations in captivity suggest that sounds may be associated with courtship displays. The series of booms in particular were observed to be associated with a conspicuous display directed by a presumptive male towards a conspecific female while it exhibited a bright silver colour pattern. Such bright colouration usually appears in patrolling, dominant males and remains during spawning behaviours in E. marginatus (Louisy, 1996). The associated display has also been described in E. marginatus by Zabala et al. $(1997 a, b)$ as occurring both during patrolling by males and in the early phases of courtship. Similar colour patterns (indicating sexual dimorphism during the reproduction period and imminent spawning), sometimes associated with sound production, have been reported in other male groupers, e.g. Mycteroperca tigris (Valenciennes 1833) (Sadovy et al., 1994), M. bonaci (Paz \& Sedberry, 2007), E. morio (Nelson et al., 2011), E. striatus (Archer et al., 2012) and M. venenosa (Schärer et al., 2012a). The occurrence of sounds during the spawning period and their potential association with visual displays as observed in captivity may suggest a link between 

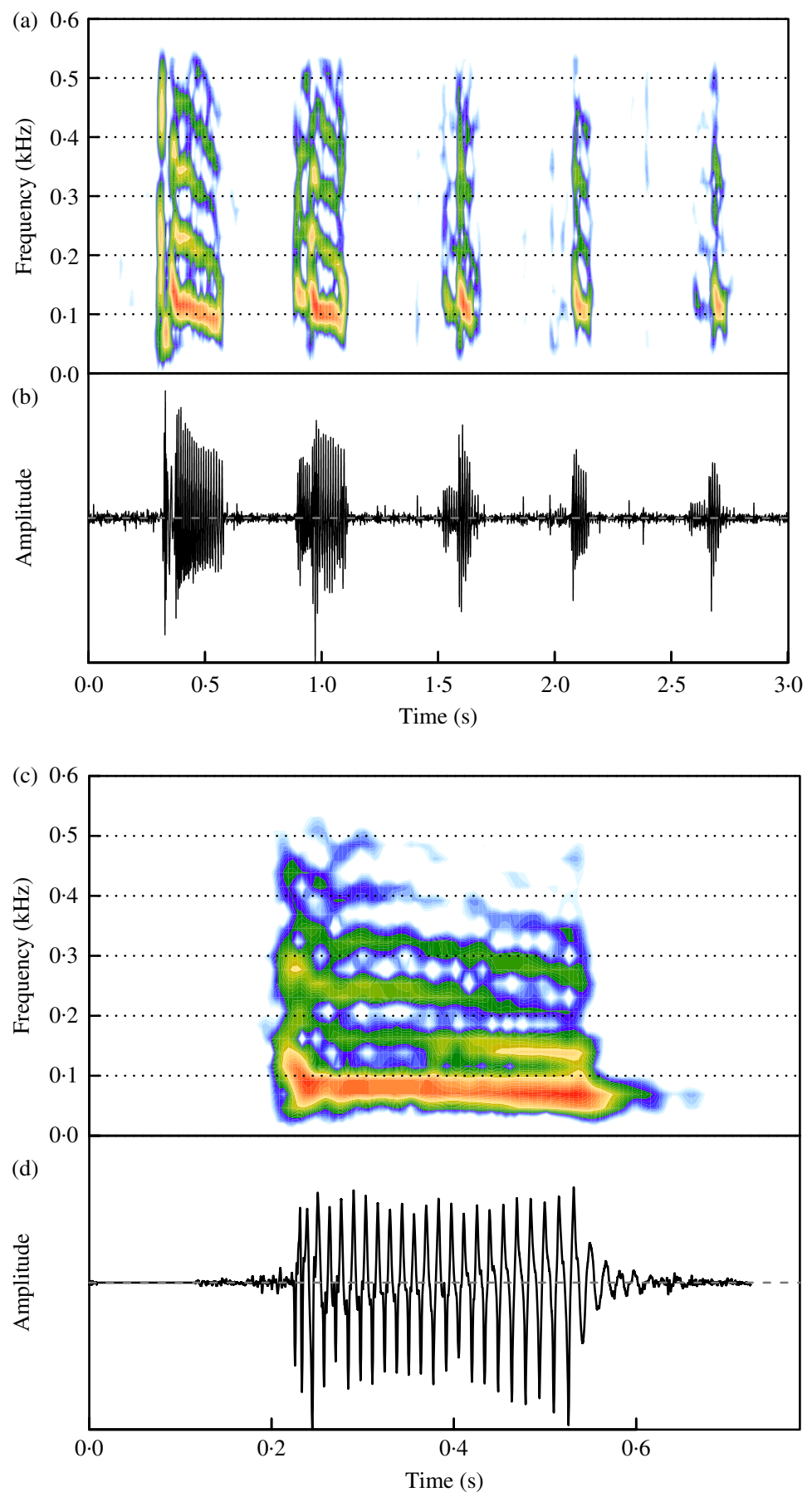

FIG. 6. (a) Spectrogram and (b) oscillogram of a series of five growls. Note that the first call is preceded by a single boom and that the second, third and fifth calls overlap with a second series of calls present in the background. (c) Spectrogram and (d) oscillogram of a growl produced by Epinephelus marginatus. Colours indicate relative sound intensity (blue $=$ low and red $=$ high). 

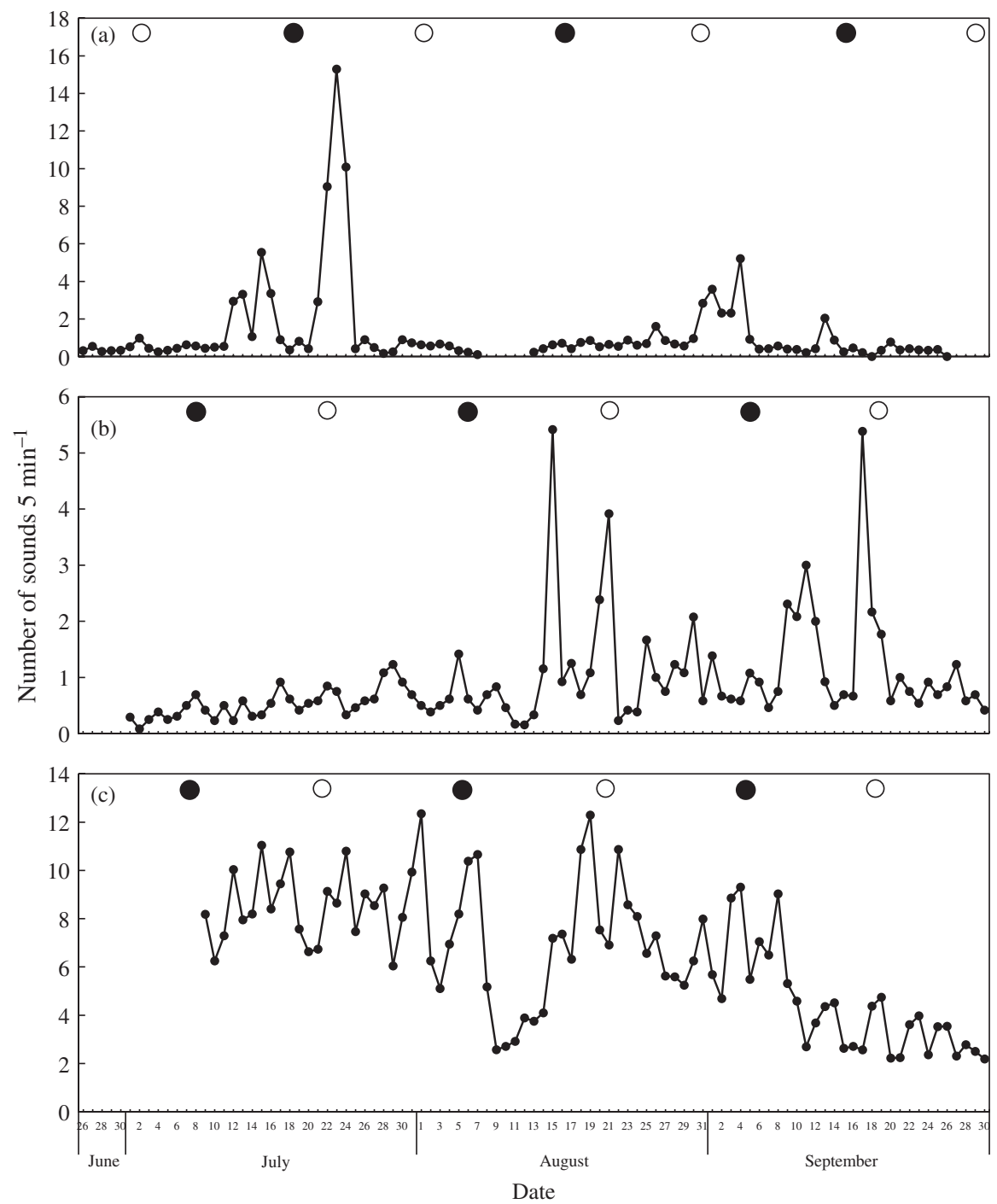

FIG. 7. Daily sound production of Epinephelus marginatus and moon cycle at La Revellata in (a) 2012, (b) 2013 and in Cerbère-Banyuls reserve in (c) 2013. Number of sounds is given for $5 \mathrm{~min} \mathrm{~h}^{-1}$ of recording. The 8 day gap ( 5 to 13 August) present in 2012 was due to technical (downloading files and changing batteries) and meteorological issues before re-immersing the device. Data are for all sound types. $\bullet, \bigcirc$, moon phases.

sonic activity and reproductive behaviour in E. marginatus. Sounds were also produced in captivity towards heterospecifics, however, implying that booming sounds might have other functions such as antagonistic or aggressive. Further observations are needed to define more precisely the behaviour patterns associated with sound production. Even though sounds were predominantly detected at dusk and during the night when reproductive activities usually take place, no observation of direct concurrence between sound production and spawning events were made in this study or in other species of groupers. Future studies should help to understand the 

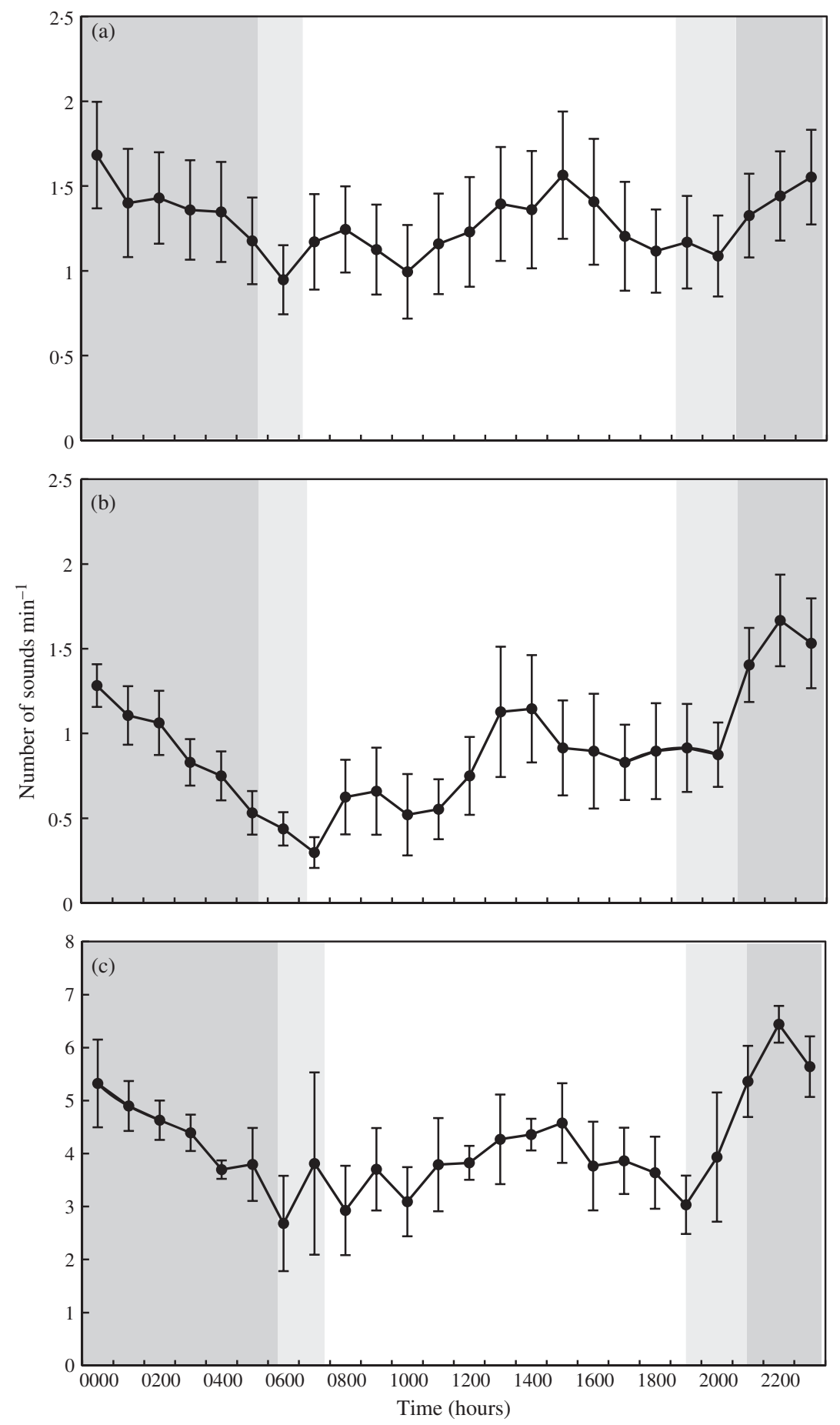

FIG. 8. Diel cycle of booming sound production of Epinephelus marginatus at La Revellata in (a) 2012, in (b) 2013 and in Cerbère-Banyuls reserve in (c) 2013. Values are mean \pm s.D. number of sounds $\mathrm{min}^{-1}$ of recording. , longest nights; $\square$, shortest nights of the recording periods. 


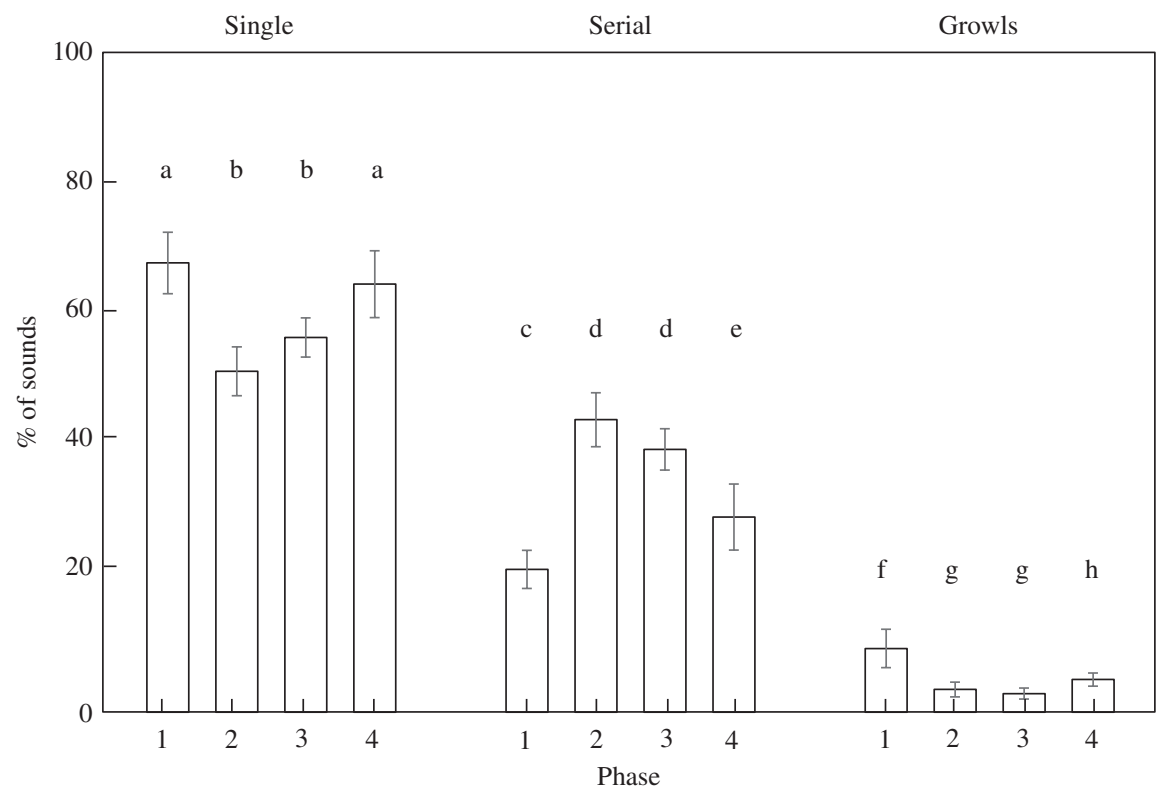

FIG. 9. Distribution of single booms, serial booms and growls of Epinephelus marginatus $\mid$ throughout the day. Phase 1: 0000 to 0500 hours, phase 2: 0600 to 1100 hours, phase 3: 1200 to 1700 hours and phase 4: 1800 to 2300 hours in Cerbère-Banyuls reserve. Values are mean \pm S.D. Different lower-case letters indicate significant differences $(P<0 \cdot 05$, Fisher post hoc test $)$.

relationships between sound production and spawning events. In sciaenids, Aalbers \& Drawbridge (2008) reported an increased calling activity with the use of a specific sound type during gamete release in the white seabass Atractoscion nobilis (Ayres 1860). As interactions during the spawning period take place in the presence of several aggregated conspecifics, the use of different sound types and the possible association of acoustic and visual modalities may provide a mechanism to synchronize spawnings. Conversely, Locascio et al. (2012) found a negative relationship between the levels of sound production and egg production in the black drum Pogonias cromis (L. 1766). Finally, Connaughton \& Taylor (1996) observed the cessation of vocalizations during gamete release in the weakfish Cynoscion regalis (Bloch \& Schneider 1801). A particular need remains to confidently attribute growling sounds to E. marginatus and to identify associated behaviours. The growling and low-pitched nature of these sound types, however, are comparable with similar types of sounds reported for other groupers (Table I) and are therefore probably produced by E. marginatus. Growl-like sounds, which might be the result of rapidly repeated overlapping pulses (Torricelli et al., 1990), are often produced after a single boom and are also associated with visual courtship displays, i.e. twitching and white-coloured pattern, as also observed in other representatives of the family Serranidae (Table I). Overall, low-pitched booming and growling sounds appear typical of groupers. The similarity of sound types and characteristics among groupers suggest a common mechanism for sound production. This mechanism is probably similar to the mechanism described in E. striatus by Hazlett \& Winn (1962). Further studies are however needed to better understand this mechanism. 


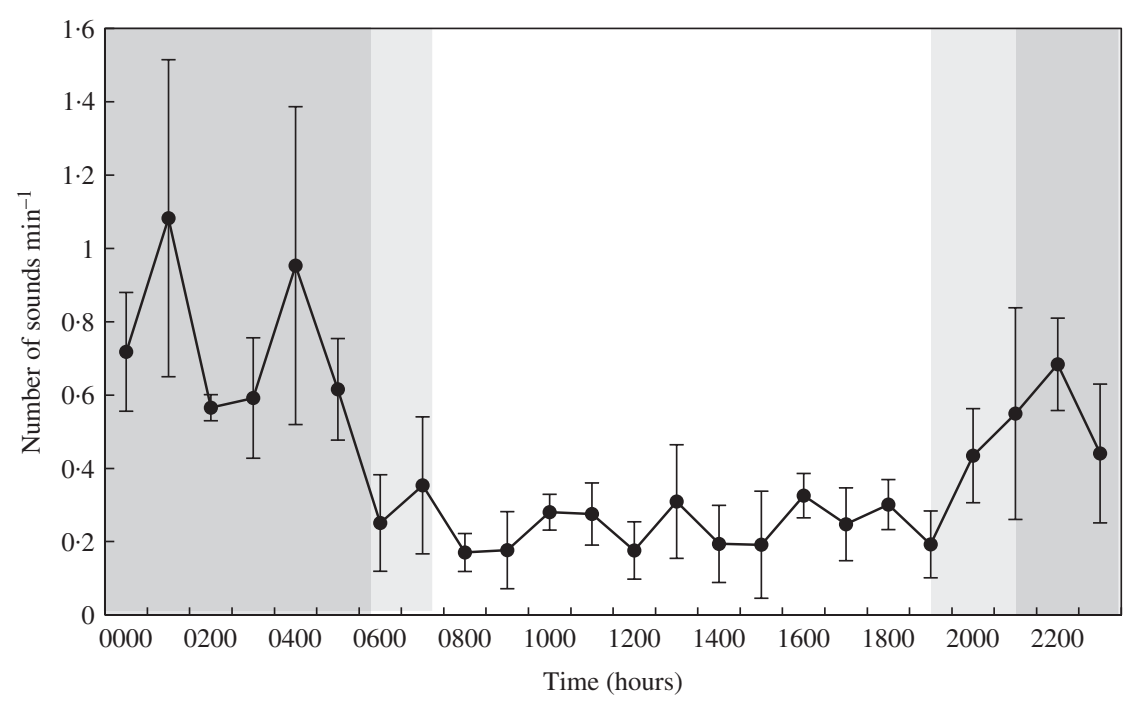

FIG. 10. Diel cycle of growl production of Epinephelus marginatus in Cerbère-Banyuls reserve in 2013. Values are mean \pm S.D. number of sounds $\min ^{-1}$ of recording. $\quad$, longest nights; $\square$, shortest nights of the recording periods.

Interspecific dissimilarities appear to exist, however, in the diel pattern of sound production. Epinephelus itajara appears to vocalize at night between 0100 and 0400 hours (Mann et al., 2009), E. morio produces sounds principally during the day with call number increasing just before dawn, peaking in the late afternoon and decreasing after dusk (Nelson et al., 2011) while M. venenosa vocalizes especially after sunset (Schärer et al., 2012a). During the spawning season, E. marginatus exhibits a clear circadian pattern with most spawns observed at dusk and around sunset (Zabala et al., 1997a; Hereu et al., 2006). A consistent pattern was observed in this study for sound production with an increase in the number of sounds from 1900 to 2200 hours before decreasing during the night. From this observation, sound production may be associated with behaviour patterns preceding or associated with spawning. At the seasonal level, increases in sound production activities detected at La Revellata in 2012 and 2013 are similar to the pattern of spawning events observed in this species by Hereu et al. (2006) in the Medes Islands (Spain). In Spain, two peaks of spawning activity were detected each summer in August, each one lasting 2-8 days separated by 1 week. Mann \& Lobel (1995) made similar observations for sonic activity in the damselfish Dascyllus albisella Gill 1862 in which sound production regularly varies along the spawning cycle increasing before nesting, peaking before spawning after which it decreases during brood care. In both species, the onset of spawning cannot be related to biotic or abiotic factors. The patterns detected at La Revellata and in Cerbère-Banuyls in 2013 were not the same. In Corsica, acoustic activity varied from year to year at the level of both the amount of sounds and the duration of the peaks. The level of sonic activity was higher and more constant in Cerbère-Banyuls. A similar continuous activity was observed for spawning in summer in 1999 by Hereu et al. (2006). In the same way, some variations in sound production cycles at the monthly level were also observed in two geographically separated populations of E. guttatus suggesting 
different reproductive cycles (Mann et al., 2010). Hereu et al. (2006) observed that spawning events were detected when the water surface temperature reached $21.8^{\circ} \mathrm{C}$, in late May to early June. During the 2012 recording period, the sea surface temperature was above this threshold, varying from $23.5^{\circ} \mathrm{C}$ in June to $28.1^{\circ} \mathrm{C}$ in August.

Sound production also showed a slight increase during the day, i.e. from the morning until the beginning of the afternoon, which may suggest that sounds may be associated with other social activities not only occurring at dusk. In different sciaenid species, such as in $C$. regalis, calls have been shown to serve in the formation of spawning aggregations, rallying individuals to the same spawning site (Mok \& Gilmore, 1983; Connaughton \& Taylor, 1995). Here, only the results for the 3 month period during which most spawning activity is known to occur are presented. Further recordings should be made beyond this spawning season to investigate whether sounds can be produced throughout the year and may have other social roles.

Likewise, monitoring oceanographic variables (e.g. water temperature) at recording sites would help with understanding the periodicity of spawning events and vocal activity. In poikilotherms, water temperature is an important variable as it affects gonadal maturation and neuro-motor activity (Walker, 1975; Hutchings \& Myers, 1994). Changes in neuro-motor activity would subsequently affect the characteristics of the sounds by modulating muscular activity (Connaughton et al., 2000; Papes \& Ladich, 2011). Further investigations at these locations would additionally provide important information on how this species responds to human-generated noise and how marine protected areas benefit this species. The use of passive acoustics and the deployment of large arrays of hydrophones may be an alternative for large-scale mapping of fish distribution based on their vocal activity (Rowell et al., 2012; Wall et al., 2012). While visual monitoring remains essential to fully describe reproductive behaviour, acoustic surveys appear valuable for locating spawning aggregation sites, providing information on the beginning and duration of the spawning season and for studying the behavioural responses of fishes during this critical period.

In conclusion, passive acoustic recordings made during this study have allowed, for the first time, the acoustic repertoire of this popular Mediterranean fish to be characterized and to establish the pattern of calling at different times of day during its spawning season. This type of data may be of particular interest for monitoring protected species and for planning management strategies.

The authors would like to thank all the teams of the STARESO and the Natural Marine Reserve of Cerbère-Banyuls for their technical support. Many thanks to M. Bournonville (Liège Museum-Aquarium), P. Y. Bouis (Cité de la Mer de Cherbourg), J. Loubet and P. Romans (Aquarium de Banyuls sur Mer) for their help and reception. F.B. was supported by a post-doctoral study grant of the Fyssen Foundation.

\section{Supporting Information}

Supporting Information may be found in the online version of this paper:

Video S1. Video footage of the twitching behaviour of a presumptive male Epinephelus marginatus produced towards a presumptive female, recorded in the aquarium of La Cité de la Mer in Cherbourg (France). Sound is turned on before the emission of the associated serial booms. 


\section{References}

Aalbers, S. A. \& Drawbridge, M. A. (2008). White seabass spawning behavior and sound production. Transactions of the American Fisheries Society 137, 542-550.

Archer, S. K., Heppel, S. A., Semmens, B. X., Pattengill-Semmens, C. V., Bush, P. G., McCoy, C. M. \& Johnson, B. C. (2012). Patterns of color phase indicate spawn timing at a Nassau grouper Epinephelus striatus spawning aggregation. Current Zoology 58, 73-83.

Bruslé, J. \& Bruslé, S. (1976). Contribution à l'étude de la reproduction de deux espèces de mérous (Epinephelus aeneus et Epinephelus guaza) des côtes de Tunisie. Revue des Travaux de l'Institut de Pêches Maritimes de Nantes 39, 313-320.

Coll, J., Linde, M., Garcia-Rubies, A., Riera, F. \& Grau, A. M. (2004). Spear fishing in the Balearic Islands (west central Mediterranean): species affected and catch evolution during the period 1975-2001. Fisheries Research 70,97-111.

Connaughton, M. A. \& Taylor, M. H. (1995). Seasonal and daily cycles in sound production associated with spawning in the weakfish, Cynoscion regalis. Environmental Biology of Fishes 42, 233-240.

Connaughton, M. A. \& Taylor, M. H. (1996). Drumming, courtship, and spawning behavior in captive weakfish, Cynoscion regalis. Copeia 1996, 195-199.

Connaughton, M. A., Taylor, M. H. \& Fine, M. L. (2000). Effects of fish size and temperature on weakfish disturbance calls: implication for the mechanism of sound generation. Journal of Experimental Biology 203, 1503-1512.

Fish, M. P. \& Mowbray, W. H. (1970). Sounds of Western North Atlantic Fishes. Baltimore, MD: Johns Hopkins Press.

Harmelin, J. G. \& Harmelin-Vivien, M. (1999). A review on habitat, diet and growth of the dusky grouper Epinephelus marginatus (Lowe, 1834). Marine Life 9, 11-20.

Hawkins, A. D. \& Amorim, M. C. P. (2000). Spawning sounds of the male haddock, Melanogrammus aeglefinus. Environmental Biology of Fishes 59, 29-41.

Hazlett, B. \& Winn, H. E. (1962). Sound producing mechanism of the Nassau grouper, Epinephelus striatus. Copeia 1962, 447-449.

Heemstra, P. C. \& Randall, J. E. (1993). FAO species catalogue 16: Groupers of the world (Family Serranidae, Subfamily Epinephelinae) - an annotated and illustrated catalogue of the grouper, rockcod, hind, coral grouper and lyretail species known to date. FAO Fisheries Synopsis 125.

Hereu, B., Diaz, D., Pasqual, J., Zabala, M. \& Sala, E. (2006). Temporal patterns of spawning of the dusky grouper Epinephelus marginatus in relation to environmental factors. Marine Ecology Progress Series 325, 187-194.

Hutchings, J. A. \& Myers, R. A. (1994). Timing of cod reproduction: interannual variability and the influence of temperature. Marine Ecology Progress Series 108, 21-31.

Irigoyen, A. J., Galvan, D. E. \& Venerus, L. A. (2005). Occurrence of dusky grouper Epinephelus marginatus (Lowe, 1834) in gulfs of northern Patagonia, Argentina. Journal of Fish Biology 67, 1741-1745.

Johnston, C. E. \& Johnson, D. L. (2000). Sound production during the spawning season in cavity-nesting darters of the subgenus Catonotus (Percidae: Etheostoma). Copeia 2000, $475-481$.

La Mesa, G., Louisy, P. \& Vacchi, M. (2002). Assessment of microhabitat preferences in juveniles dusky grouper (Epinephelus marginatus) by visual sampling. Marine Biology 140, $175-185$.

Ladich, F. \& Myrberg, A. A. Jr. (2006). Agonistic behavior and acoustic communication. In Communication in Fishes (Ladich, F., Collin, S. P., Moller, P. \& Kapoor, B. G., eds), pp. 121-148. Enfield, NH: Science Publishers.

Lembo, G., Spedicato, M. T., Okland, F., Carbonara, P., Fleming, I. A., McKinley, R. S., Thorstad, E. B., Sisak, M. \& Ragonese, S. (2002). A wireless communication system for determining site fidelity of juvenile dusky groupers Epinephelus marginatus (Lowe, 1834) using coded acoustic transmitters. Hydrobiologia 483, 249-257.

Mann, D. A. \& Lobel, P. S. (1995). Passive acoustic detection of sounds produced by the damselfish, Dascyllus albisella (Pomacentridae). Bioacoustics 6, 199-213.

Locascio, J. V. \& Mann, D. A. (2008). Diel periodicity of fish sound production in Charlotte Harbor, Florida. Transactions of the American Fisheries Society 137, 606-615. 
Locascio, J. V., Burghart, S. \& Mann, D. A. (2012). Quantitative and temporal relationships of egg production and sound production by black drum Pogonias cromis. Journal of Fish Biology 81, 1175-1191.

Louisy, P. (1996). Principaux patrons de coloration du mérou brun de Mediterranée Epinephelus marginatus (Lowe, 1834) (Pisces: Serranidae) en periode d'activité reproductrice. Revue Française d'Aquariologie 23, 21-32.

Luczkovich, J. J., Sprague, M. W., Johnson, S. E. \& Pullinger, R. C. (1999). Delimiting spawning areas of weakfish, Cynoscion regalis (Family Sciaenidae) in Pamlico Sound, North Carolina using passive hydroacoustic surveys. Bioacoustics 10, 143-160.

Luczkovich, J. J., Mann, D. A. \& Rountree, R. A. (2008). Passive acoustics as a tool in fisheries science. Transactions of the American Fisheries Society 137, 533-541.

Malavasi, S., Valerio, C. \& Torricelli, P. (2009). Courtship sounds and associated behaviours in the Canestrini's goby Pomatoschistus canestrinii. Journal of Fish Biology 75, $1883-1887$.

Mann, D. A., Locascio, J. V., Coleman, F. C. \& Koenig, C. C. (2009). Goliath grouper Epinephelus itajara sound production and movement patterns on aggregation sites. Endangered Species Research 7, 229-236.

Mann, D., Locascio, J., Schärer, M., Nemeth, M. \& Appeldoorn, R. (2010). Sound production by red hind (Epinephelus guttatus) in spatially segregated spawning aggregations. Aquatic Biology 10, 149-154.

Marino, G., Azzurro, E., Massari, A., Finoia, M. G. \& Mandich, A. (2001). Reproduction in the dusky grouper from the southern Mediterranean. Journal of Fish Biology 58, 909-927.

McKibben, J. R. \& Bass, A. H. (1998). Behavioral assessment of acoustic parameters relevant to signal recognition and preference in a vocal fish. Journal of the Acoustical Society of America 104, 3520-3533.

Mok, H. K. \& Gilmore, R. G. (1983). Analysis of sound production in estuarine fish aggregations of Pogonias cromis, Bairdiella chrysoura, and Cynoscion nebulosus (Sciaenidae). Bulletin of the Institute of Zoology, Academia Sinica 22, 157-186.

Myrberg, A. A. Jr. \& Lugli, M. (2006). Reproductive behavior and acoustic communication. In Communication in Fishes (Ladich, F., Collin, S. P., Moller, P. \& Kapoor, B. G., eds), pp. 149-176. Enfield, NH: Science Publishers.

Nelson, M. D., Koenig, C. C., Coleman, F. C. \& Mann, D. A. (2011). Sound production of red grouper Epinephelus morio on the West Florida Shelf. Aquatic Biology 12, 97-108.

Papes, S. \& Ladich, F. (2011). Effects of temperature on sound production and auditory abilities in the striped raphael catfish Platydoras armatulus (Family Doradidae). PLoS One 6, e26479.

Parmentier, E., Kéver, L., Casadevall, M. \& Lecchini, D. (2010). Diversity and complexity in the acoustic behaviour of Dascyllus flavicaudus (Pomacentridae). Marine Biology 157, 2317-2327.

Parmentier, E., Kéver, L., Boyle, K., Corbisier, Y. E., Sawelew, L. \& Malavasi, S. (2013). Sound production mechanism in Gobius paganellus (Gobiidae). Journal of Experimental Biology 216, 3189-3199.

Pastor, J., Verdoit-Jarraya, M., Astruch, P., Dalias, N., Nelva Pasqual, J. S., Saragoni, G. \& Lenfant, P. (2009). Acoustic telemetry survey of the dusky grouper (Epinephelus marginatus) in the Marine Reserve of Cerbère-Banyuls: informations on the territoriality of this emblematic species. Comptes Rendus de Biologie 332, 732-740.

Paz, G. \& Sedberry, G. R. (2007). Identifying black grouper (Mycteroperca bonaci) spawning aggregations off Belize: conservation and management. Proceedings of the Gulf and Caribbean Fisheries Institute 60, 577-584.

Reñones, O., Goñi, R., Pozo, M., Deudero, S. \& Moranta, J. (1999). Effects of protection on the demographic structure and abundance of Epinephelus marginatus (Lowe, 1834). Evidence from the Cabrera Archipelago National Park (West-Central Mediterranean). Marine Life 9, 45-53.

Reñones, O., Grau, A., Mas, X., Riera, F. \& Saborido-Rey, F. (2010). Reproductive pattern of an exploited dusky grouper Epinephelus marginatus (Lowe 1834) (Pisces: Serranidae) population in the western Mediterranean. Scientia Marina 74, 523-537. 
Rowell, T. J., Schärer, M. T., Appeldoorn, R. S., Nemeth, M. I., Mann, D. A. \& Rivera, J. A. (2012). Sound production as an indicator of red hind density at a spawning aggregation. Marine Ecology Progress Series 462, 241-250.

Sadovy, Y. J., Colin, P. L. \& Domeier, M. L. (1994). Aggregation and spawning in the tiger grouper, Mycteroperca tigris (Pisces: Serranidae). Copeia 1994, 511-516.

Schärer, M. T., Nemeth, M. I., Mann, D., Locascio, J., Appeldoorn, R. S. \& Rowell, T. J. (2012a). Sound production and reproductive behavior of yellowfin grouper, Mycteroperca venenosa (Serranidae) at a spawning aggregation. Copeia 2012a, 135-144.

Schärer, M. T., Rowell, T. J., Nemeth, M. I. \& Appeldoorn, R. S. (2012b). Sound production associated with reproductive behavior of Nassau grouper Epinephelus striatus at spawning aggregations. Endangered Species Research 19, 29-38.

Schärer, M. T., Nemeth, M. I., Rowell, T. J. \& Appeldoorn, R. S. (2014). Sounds associated with reproductive behavior of the black grouper (Mycteroperca bonaci). Marine Biology 161, $141-147$.

Tavolga, W. N. (1968). Fishes. In Animal Communication (Sebeok, T. A., ed.), pp. 271-288. Bloomington, IN: Indiana University Press.

Torricelli, P., Lugli, M. \& Pavan, G. (1990). Analysis of sounds produced by male Padogobius martensi (Pisces, Gobiidae) and factors affecting their structural properties. Bioacoustics 2, 261-275.

Walker, T. J. (1975). Effects of temperature on rates in poikilotherm nervous systems: evidence from the calling songs of meadow Katydids (Orthopera: Tettigoniidae: Orchelimum) and re-analysis of published data. Journal of Comparative Physiology A 101, 57-69.

Wall, C. C., Lembke, C. \& Mann, D. A. (2012). Shelf-scale mapping of sound production by fishes in the eastern Gulf of Mexico, using autonomous glider technology. Marine Ecology Progress Series 449, 55-64.

Zabala, M., Garcia-Rubieas, A., Louisy, P. \& Sala, E. (1997a). Spawning behaviour of the Mediterranean dusky grouper Epinephelus marginatus (Lowe, 1834) (Pisces, Serranidae) in the Medes Islands Marine Reserve (NW Mediterranean, Spain). Scientia Marina 61, $65-77$.

Zabala, M., Louisy, P., Garcia-Rubieas, A. \& Gracia, V. (1997b). Socio-behavioural context of reproduction in the Mediterranean dusky grouper Epinephelus marginatus (Lowe, 1834) (Pisces, Serranidae) in the Medes Islands Marine Reserve (NW Mediterranean, Spain). Scientia Marina 61, 79-98.

\section{Electronic Reference}

Cornish, A. \& Harmelin-Vivien, M. (2004). Grouper \& Wrasse Specialist Group: Epinephelus marginatus. The IUCN Red List of Threatened Species 2015.2. Available at http://www. iucnredlist.org/details/7859/0 